\title{
The benthic macroinvertebrate community of lagoa Da Sancha: a coastal lagoon in SW Portugal
}

\author{
Luis Cancela da Fonseca ${ }^{1}$, Ana Manuel Costa ${ }^{2}$, Filomena Magalhães ${ }^{3} \&$ Margarida Cristo ${ }^{4}$. \\ ${ }^{1}$ IMAR e UCTRA, Universidade do Algarve, Campus de Gambelas, P-8000 FARO. Present adress: IPIMAR- \\ CRIP Sul. P-8700-305 Olhão. \\ ${ }^{2}$ IMAR e Dept. de Ecologia, Universidade de Évora, Rua Romão Ramalho 59, P-7000 ÉVORA; \\ ${ }^{3}$ IMAR, Laboratório Marítimo da Guia, Estrada do Guincho, P- 2750 CASCAIS; \\ ${ }^{4}$ CCMAR e UCTRA, Universidade do Algarve, Campus de Gambelas, P-8000 FARO.
}

\begin{abstract}
A one year sampling programme (February 1988, March 1989) was carried out in the Lagoa da Sancha as part of an ecological characterisation of the Alentejo littoral lagoonal systems. Lagoa da Sancha is North of the locality of Sines, and spreads over an area of approximately 4 ha. It has an elongate shape along a N-S axis, and receives water from a hydrographic basin of approximately $37 \mathrm{~km}^{2}$. The lagoon can be considered a system in which communication with the sea, which could provide its renewal, is naturally established only very seldom according to local fishermen (an inlet has existed only once in the past 25 years). Overwash is the main source of sea water. This is revealed by salinity values, always below 5\%o (oligohaline), except for summer values, when values, may reach $12 \%$ o (mesohaline) due to evaporation. Of the 69 invertebrate taxa found, $89.8 \%$ can be considered as continental and $8.7 \%$ of lagoonal affinities (i.e. lagoonal-continental). Only few groups were present throughout the year, with a constant presence of continental species (e.g. Daphnia sp, Herpetocypris reptans, Cloeon sp., Plea leachi, Berosus sp., Chironomidae). Anomopoda and Chironomidae were the dominant groups. Individuals of brackish lagoonal species were rare during the sampling period. Results show this benthic community is very similar to that of temporary lentic systems, where the taxa succession is erratic.
\end{abstract}

Key words: Benthic macroinvertebrates, brackish coastal lagoons, oligohaline environments.

\section{RESUMEN}

Como parte de un programa de caracterización ecológica de los sistemas de lagunas litorales del Alentejo se realizó un programa de muestreo de un año (de Febrero de 1988 a Marzo de 1989) en el Lago da Sancha. Esta laguna esta situada al Norte del Sines y se extiende sobre un área aproximada de 4 ha con una forma alargada a lo largo del eje $N$-S. La laguna recibe agua de una cuenca de unos $37 \mathrm{~km}^{2}$ aproximadamente. La laguna puede considerarse como un sistema maduro en el cual la comunicación con el mar, que facilitaría la renovación del agua, se establece de forma natural muy raramente (según un pescador de la zona, en los últimos 25 años tan solo una vez se ha establecido comunicación con el mar). La entrada superficial es la única fuente de entrada de agua proveniente del mar. Este hecho queda patente por los valores de salinidad, siempre por debajo del $5 \%$ (oligohalino), con excepción de los valores de verano, que, debido a la fuerte evaporación, pueden alcanzar el 12\%o (mesohalino). De los 69 taxones de invertebrados que se han hallado, 89.8\% se pueden considerar continentales y el $8.7 \%$ de afinidad continental-lagunar salobre. El número de grupos presentes a lo largo del año fue reducido, con una presencia constante de especies de afinidad continental (Daphnia sp., Herpetocypris reptans, Cloeon $s p$. ., Plea leachi, Berosus sp., Chironomidae). Anomopoda y Chironomidae fueros los grupos dominantes. Los individuos de especies de lagunas salobres fueros raros durante el período de muestreo. Los resultados muestran que esta comunidad bentónica era muy similar a aquellas de los sistemas lagunares leníticos en los que la sucesión de taxones es errática.

Palabras clave: Macroinvertebrados bentónicos, lagunas costeras salobres, ambientes oligohalinos.

Limnetica 16: 39-48 (1999)

(C) Asociación Española de Limnología, Madrid. Spain. ISSN: 0213-8409. 


\section{INTRODUCTION}

Several processes can transform a coastal littoral zone into a lagoon. Coastal lagoons may originate by the transgression of seawater into previously extending freshwater lakes, by the invasion of land below sea level after storms have breached coastal defence systems, during reclamation of salt-marshes or by barrier formation in estuaries. Coastal lagoons are important reservoirs of continental material where, as a rule, exceptional primary production conditions prevail and may disrupt these ecosystems, leading to dystrophic phenomena. However, each lagoon is a case unto itself. They are comparatively simple systems and are therefore easily disturbed both by natural perturbation and by pollution or adjacent urban and industrial development.

In a typical lagoon, the exchange and mixture of saltwater and freshwater is irregular and the hydrography of a lagoon may show fluctuations daily, seasonally, and over longer periods of time (Colombo, 1977). Thus, the ecology of coastal lagoons is largely determined by freshwater inputs and by mixing and exchange processes with the adjacent sea. The water budget of a lagoon, with its freshwater and marine components, also determines sedimentation and sediment patterns (Postma, 1981). Part of the accumulated allochthonous and autochthonous material is exported to the sea, at the same time importing an important biological component. Interactions between sea and lagoonal environments are of major importance for biogeochemical and ecological cycles ocurring in coastal lagoons.

Sediments are usually unevenly distributed over the bottom, although perhaps the most important characteristics are the large quantities of organic matter and the high water content of bottom deposits. Both organic content and water determine mechanical and chemical properties of the sediment. Any shallow water body high in nutrients provides ideal conditions for high production (Barnes, 1980) and restricted export in lagoons allows accumulation of the organic matter produced in shallow lagoons, sunlight is often able to reach the bottom, leading to increase the production of macrophytes, benthic microflora and phytoplankton in the water column.

The majority of lagoons accumulate more material than they export, creating areas of deposition, which leads to silting, rapid ageing and succession to swamps. Along the Portuguese SW coast several environments show different degrees of ageing, depending on their degree of exchange with the sea (Magalhães et al., 1987; Cancela da Fonseca et al., in litt.). On the other hand, small rivers with a seasonal torrential regime draining south-west Portugal do not always reach the sea directly. Discharge to the ocean is

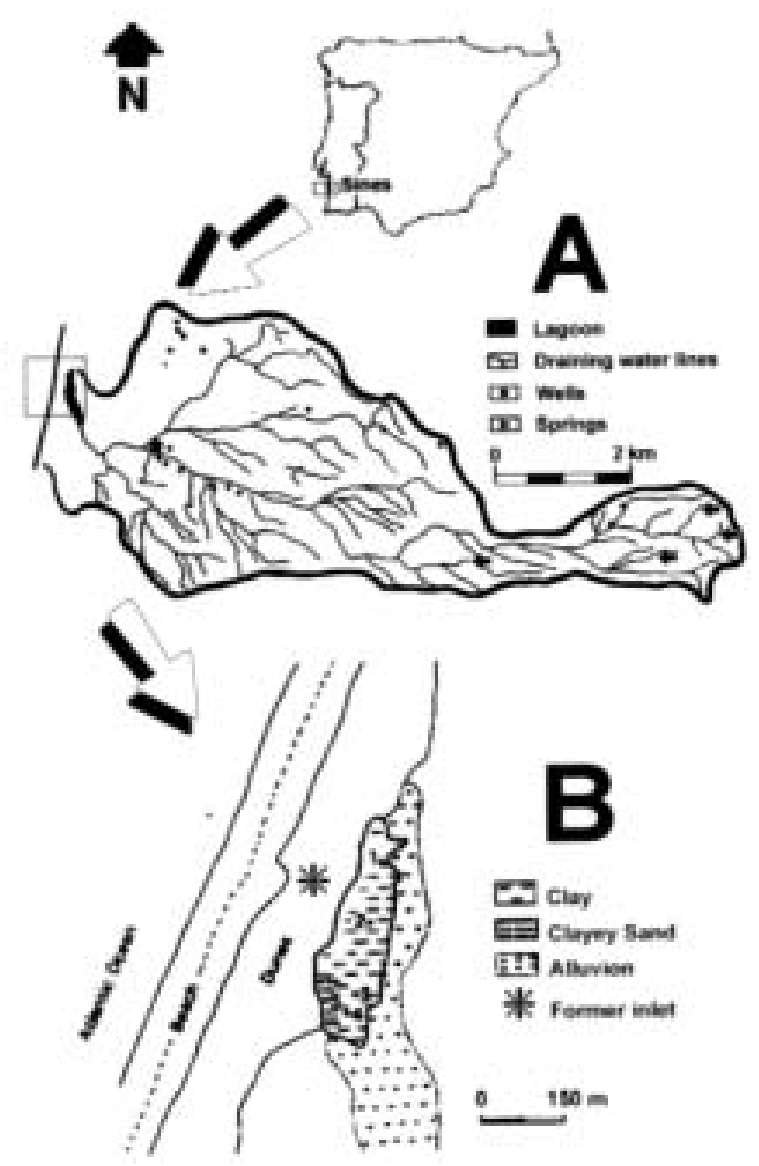

Figure 1. Geographical location of Lagoa da Sancha in the Iberian Peninsula, hydrographic basin outline (A), main sediment types and location of sampling stations (B). Situación de la laguna de Sancha en la Península Ibérica, contorno de cuenca hidrográfica (A), principales tipos de sedimento y situación de los puntos de muestreo $(B)$. 
prevented by active beach-ridges, forcing the water to accumulate in small coastal lagoons. The accumulation of large amounts of water can lead to an inlet opening, re-establishing the communication with the sea. Marine renewal and the maintenance of brackish characteristic are essential to the productivity of these systems (Costa $e t$ al., 1985; Cancela da Fonseca, 1989; Cancela da Fonseca et al., 1989a). These lagoons are usually characterised by their high primary production (i.e. plant, macro-algae, microphytobenthos and phytoplankton) and bottom sediments with high organic matter content. Production is of mainly macrophytes. Summer ecological changes generally referred to as "dystrophic crises" have been described (Bernardo et al., 1988). Depending on the magnitude of episodic fresh- and sea water inputs in winter, anoxic conditions in the stagnant bottom water may develop.

\section{STUDY AREA}

The Melides, Santo André and Sancha lagoons, located in the Alentejo coast (SW Portugal), have been studied during several years as part of a program of ecological characterisation of littoral lagoonal environments (Costa et al., 1985; Cancela da Fonseca et al., 1987; Bernardo et al., 1988; Cancela da Fonseca, 1989; Cancela da Fonseca et al., 1989a,b; Bernardo, 1990; Cancela da Fonseca et al., 1990; Duarte et al., 1990; Cristo \& Cancela da Fonseca, 1994). These lagoons present different senescence degrees, where spontaneous communication with the sea ("vivification" sensu the Italian authors) occurs unfrequently. In Melides lagoon, the formation of an inlet is still frequent, while in Sancha lagoon, and according a local fishermen an inlet was only established once in the past 25 years. Overwash during storms constitute its main source of sea water.

Lagoa da Sancha is a small (4 ha) coastal lagoon with an elongate shape along a N-S axis. The lagoon is located close to and north of the locality of Sines. Its original connection with the sea, and only way for water renewal, has been lost and, consequently, only minimal colonisation by marine species can occur. It is isolated from the sea by a sand barrier of a minimun 150 metres wide with well-developed dune vegetation, except in the zone of the old inlet channel. Freshwater comes from a small catchment area (ca. $37 \mathrm{~km}^{2}$ ) with a regime of seasonal torrential rains. The lagoonal area considered (i.e. where sampling took place and environmental parameters were measured) was the area which was flooded during the period of study. The study area included sites close to a sand barrier, with mud and sandy areas and a predominance of the macrophyte Ruppia maritima. The area was also fringed by sediments of alluvial origin and with a dense coverage of common reed (Phragmites australis)(Fig. 1). No previous studies have been done on this lagoonal environment. The area is being proposed for designation as a protected nature reserve.

\section{MATERIAL AND METHODS}

Samples were collected monthly between February 1988 and March 1989, at generally five 5 sampling stations (Fig. 1).

Temperature $\left({ }^{\circ} \mathrm{C}\right)$, salinity $(\%), \mathrm{pH}$, dissolved oxygen (ppm) and turbidity (NTU) were measured every month. Monthly water samples were also obtained for nutrient analysis, which was carried out following standard procedures described by Strickland \& Parsons (1972) for phosphate, nitrate, nitrite and silicate and by Grasshoff (1976) for ammonia. Chlorophyll $a$ and phaeopigments $\left(\mathrm{mg} \cdot \mathrm{m}^{-3}\right)$ were determined spectrophotometrically from material collected on Whatman GF/C filters, after extraction with 90\% acetone in cool and dark conditions (Lorenzen, 1967). The National Meteorological Institute provided rainfall data.

For benthic macroinvertebrates, samples were collected with a modified Van Veen grab ("Sousa Reis"/LMG 83, $0.05 \mathrm{~m}^{2}$ ). Sampling were sieved in situ through a $1 \mathrm{~mm}^{2}$ mesh sieve and preserved in a $10 \%$ formalin solution stained with Rose Bengal. After sorting, samples were kept in $4 \%$ buffered formalin solution. All organisms were 
identified to the species level whenever possible. Diversity ( $\mathrm{H}^{*}$, bits), Equitability (E) and McNaughton Community Dominance (Dc \%) indices were calculated (Krebs, 1994).

Estimates of sediment organic matter content (\%) for the top centimeter were obtained by weight loss on ignition $\left( \pm 500^{\circ} \mathrm{C}\right.$ during a $24 \mathrm{hr}$ period), after drying for $24 \mathrm{hr}$ at about $65^{\circ} \mathrm{C}$. Macrophyte biomass, measured as ash-free dry weight (i.e. AFDW g. $\mathrm{m}^{-2}$ ), was determined using the above method, from material sorted out from macroinvertebrate samples.

\section{RESULTS}

Climatic conditions - temperature and rainfall define annual patterns of most variables. The lagoon can be classified as oligohaline $(<5 \%$ o salinity), except in Summer, when salinity values reach $12 \%$ (mesohaline) due to increased evaporation and seasonal drought (Table 1). Diurnal dissolved oxygen is low (i.e. $<5 \mathrm{ppm}$ ) in Spring/Summer and in December, but is never absent. The organic content of the top centimetre of sediment averaged $25 \%$ of total dry weight (Table 1). Nutrient concentrations revealed both internal recycling and phosphate release from the bottom. Run-off from the catchment area caused an increase in nitrogen and silicate lagoon concentrations (Table 1).

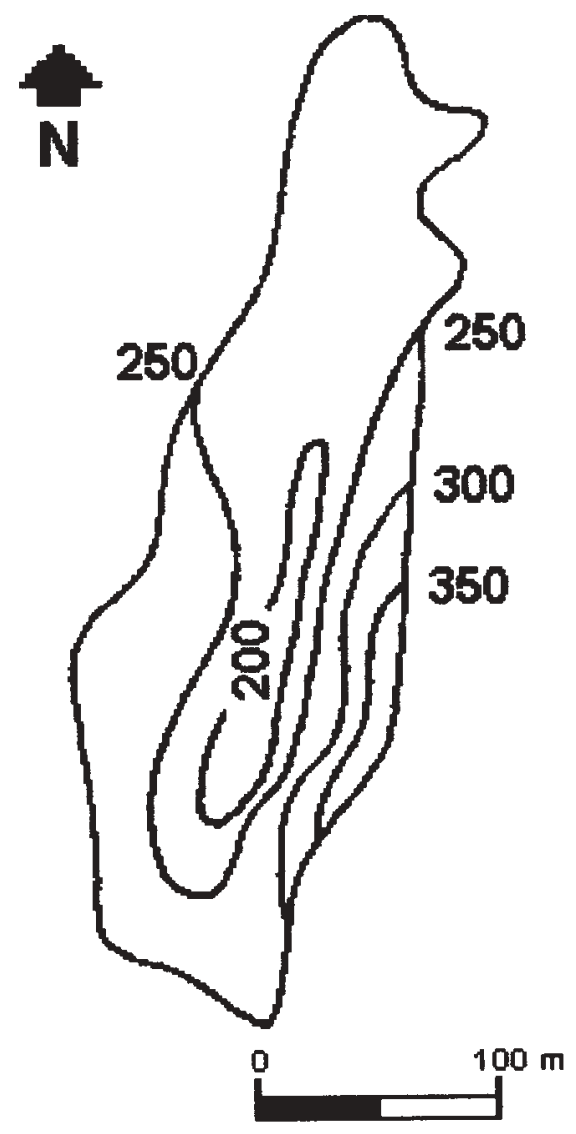

Figure 2. Average distribution of macrophyte biomass (AFDW g. $\mathrm{m}^{-2}$ ) in Lagoa da Sancha during the period February 1988- March 1989. Distribución promedio de la biomasa de macrófitos (PSSC g. $\mathrm{m}^{-2}$ ) en la laguna de Sancha durante el período de Febrero de 1988 a Marzo de 1989.

Table 1. Lagoa da Sancha: environmental parameters over the sampling period (February 1988 - March 1989). Laguna da Sancha: parámetros ambientales durante el período de muestreo (Febrero 1988-Marzo 1989).

\begin{tabular}{|c|c|c|c|c|c|c|c|c|c|c|c|c|c|c|c|}
\hline \multirow{2}{*}{$\begin{array}{l}\text { Environmental } \\
\text { parameters }\end{array}$} & \multicolumn{12}{|c|}{1988} & \multicolumn{3}{|c|}{1989} \\
\hline & Jan & Feb & Mar & Apr & May & Jun & Jul & Aug & Sept & Oct & Nov & Dec & Jan & Feb & Mar \\
\hline Temperature $\left({ }^{\circ} \mathrm{C}\right)$ & - & 12 & 16 & 18.4 & 18 & 21 & 20 & 20 & 28 & 26 & 18 & 12 & 12.8 & 16.9 & 15.7 \\
\hline Salinity $(\% 0)$ & - & 2.9 & 3 & 3 & 2.5 & 3 & 3 & 4 & 12 & 12 & 8.5 & 3 & 4.5 & 3 & 4 \\
\hline Rainfall (mm) & 1536 & 464 & 107 & 179 & 357 & 679 & 214 & 0 & 15 & 1411 & 1821 & 107 & 71 & 54 & 36 \\
\hline Macrophytes (g/m2) & - & 284.1 & 250 & 219.5 & 209.1 & 236.4 & 220.5 & 393.2 & 177.3 & - & 113.6 & 165.9 & 161.4 & 204.5 & 227.3 \\
\hline Oxygen $(\mu \mathrm{g} / \mathrm{L})$ & - & 11.9 & 11 & 7.9 & 3 & 3.4 & 4.8 & 4.4 & 10 & 9 & 6.2 & 3.9 & 13 & 9.5 & 9.1 \\
\hline Phosphates $(\mu \mathrm{g} / \mathrm{L})$ & - & 0.3 & 0.28 & 0.34 & 0.21 & 1 & 1.24 & 0.32 & 12.4 & 1.2 & 1.33 & 0.63 & 0.4 & 0.24 & 0.49 \\
\hline Nitrogen $(\mu \mathrm{g} / \mathrm{L})$ & - & 3.43 & 0 & 0 & 2.99 & 0.69 & 3.74 & 0.79 & 1 & 1.1 & 49 & 28.6 & 26.84 & 12.45 & 9.43 \\
\hline Silicates $(\mu \mathrm{g} / \mathrm{L})$ & - & 5.73 & 8.5 & 8.8 & 2.35 & 22.4 & 22.25 & 10 & 41.5 & 55 & 148 & 7.15 & 7.86 & 7.8 & 7.15 \\
\hline $\operatorname{SOM}(\%)$ & - & 29.7 & 29.3 & 28.8 & 31.4 & 30.3 & 25.7 & 23.8 & 21.1 & - & 24.3 & 19.7 & 19.5 & 25.8 & 25.7 \\
\hline
\end{tabular}


Table 2. List of taxa recorded in the benthos of Lagoa da Sancha (February 1988- March 1989). Shading indicates presence. Taxones encontrados en el bentos de la Laguna da Sancha (Febrero 1988-Marzo 1989). El sombreado indica presencia.

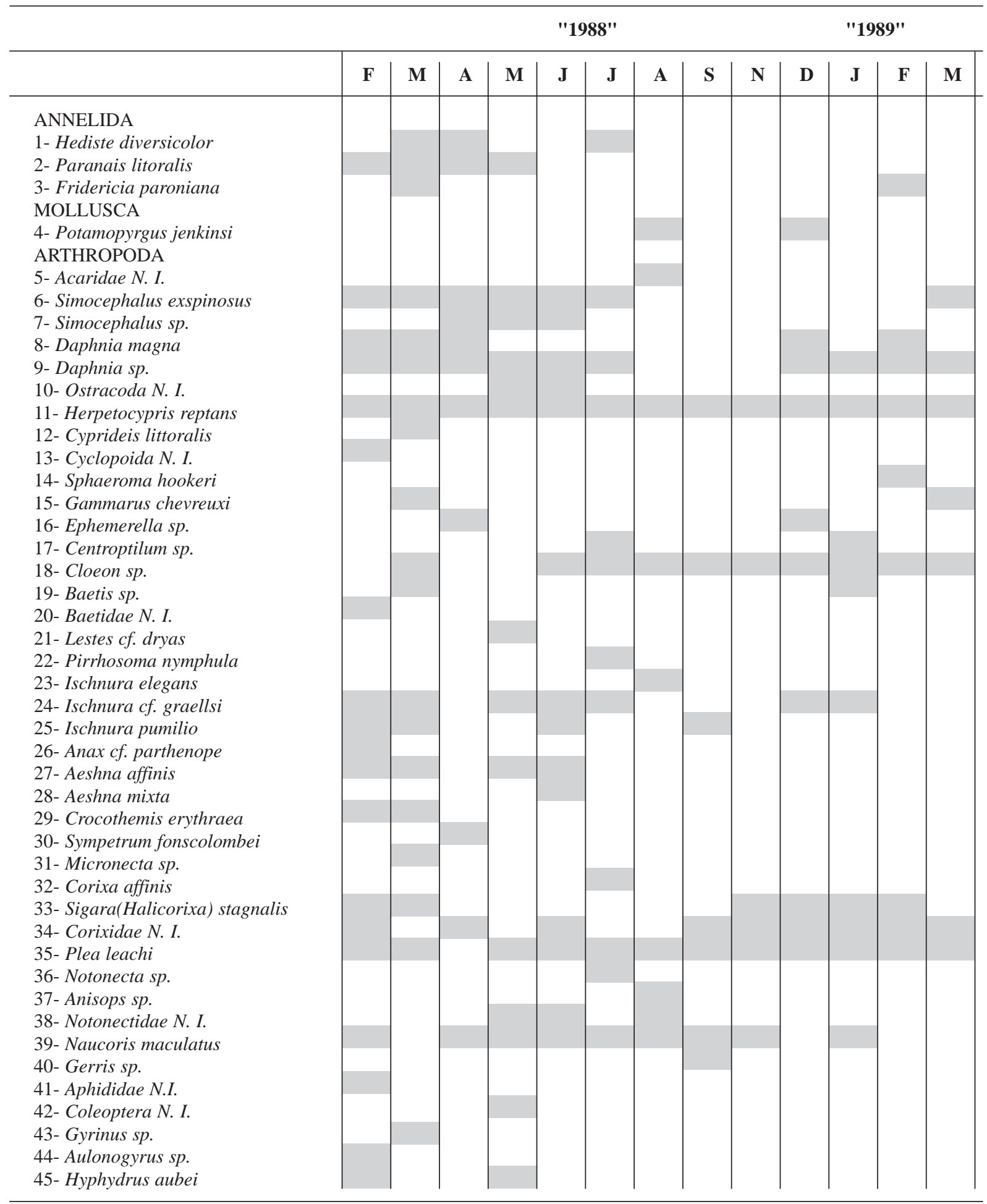


Table 2. Continuación. Continuation.

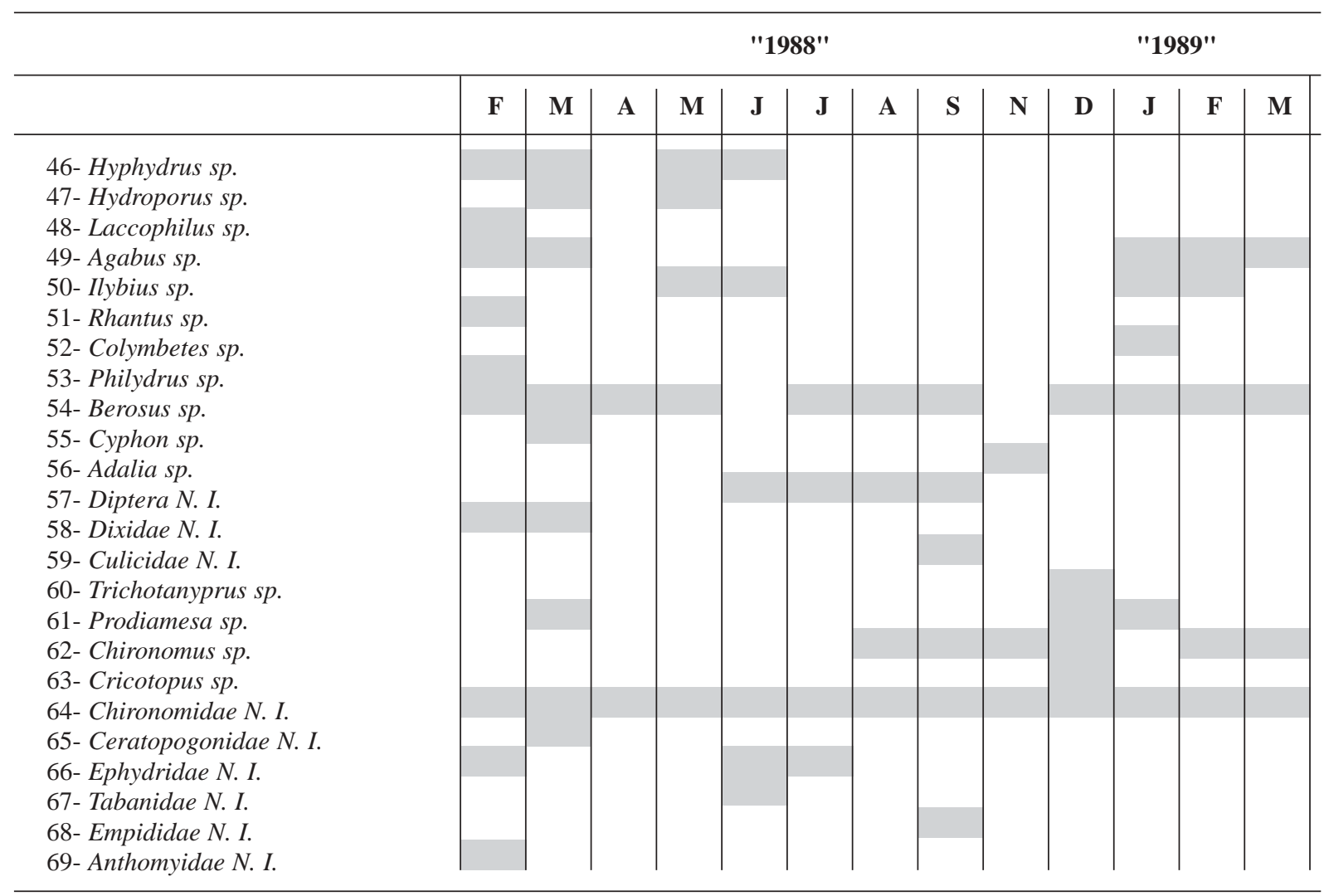

The recorded maxima for chlorophyll- $a$ and phaeopigments correspond to the detected peak of phosphate (September 1988 - Table 1).

During Summer, water volume decrease dramatically. Macrophyte biomass achieved its maximum in July (400 g AFDW/ $\mathrm{m}^{-2}$ - Table 1). Ruppia maritima was the only macrophyte species recorded in the sampled area. Its biomass decreased from the inner part towards the ancient inlet zone and into the deeper area (Fig. 2).

The sixty-nine taxa of macroinvertebrates identified belong to 14 major taxonomic groups (Table 2 ). It appears that only species with continental and/or freshwater affinities are present throughout the year. Only a reduced number of these can be considered constant in the lagoon, such as the Anomopoda Daphnia sp., the Ostracoda Herpetocypris reptans, the Ephemeroptera Cloeon $s p$. , the Hemiptera Plea leachi, the Coleoptera Berosus sp and the Diptera Chironomidae spp. Most individuals in samples $(89.4 \%)$ belonged to Anomopoda and Diptera (Fig. 3), both typically continental and freshwater groups, although with representatives in brackish environments.

Richness (i.e. number of taxa) generally decreases over the sampling period. A corresponding increase in global density (total number of individuals $/ \mathrm{m}^{2}$ ) was also observed (Fig. 4).

Monthly variation of Diversity (H', bits), Equitability (E) and McNaughton Dominance (Dc, \%) of Community (Fig. 5) emphasize that most taxa have uniform numerical distributions, a situation that was maintained until May. From June onwards, there was a decrease in diversity. In september, a peak in diversity, coincided with a decrease in dominance. In following months a 


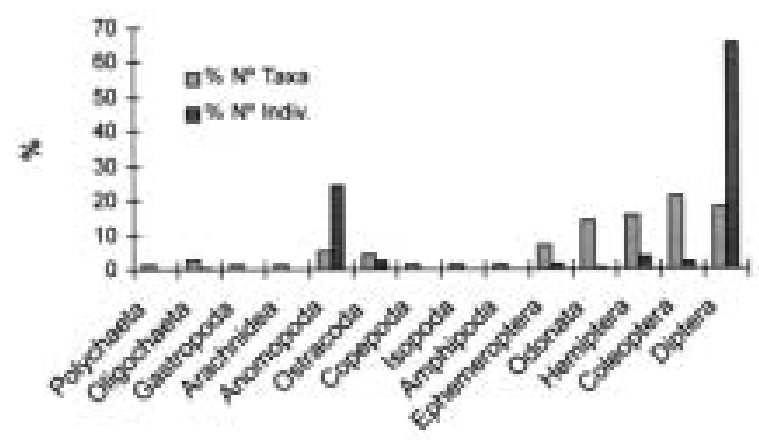

Figure 3. Percentage of taxa and percentage of number of individuals per taxa. found in Lagoa da Sancha during February 1988March 1989. Porcentage de taxones y de número de individuos por taxón encontrados en la laguna de Sancha durante el período de Febrero de 1988 a Marzo de 1989.

lower diversity was found along with higher dominance values. Generally, the decrease in diversity and increase in dominance, reflects both the decrease in the number of taxa and increase in the number of individuals. The fact that many insect taxa leave the water when reaching the adult phase, explains in part the decrease in richness.

\section{DISCUSSION}

An important component of the biological communities of coastal lagoons originates in the sea. However, only $8.7 \%$ of taxa collected in Lagoa da Sancha were marine species. The great majority of both number of taxa (89.8\%) and abundances $(89.4 \%)$ are of continental origin. An important shift of the benthic macroinvertebrate community from a meso-polyhaline to an oligohaline community has occurred because of the lack of connection with the sea. By contrast, $50 \%$ and $41.5 \%$ of taxa recorded in St. André and Melides lagoons are of marine origin (Cancela da Fonseca, 1995, Cancela da Fonseca et al., 1989b).

It can therefore be argued that the studied lagoonal community is a primarily freshwater ecosystem, very similar to temporary lentic systems where taxa succession is erratic in tight

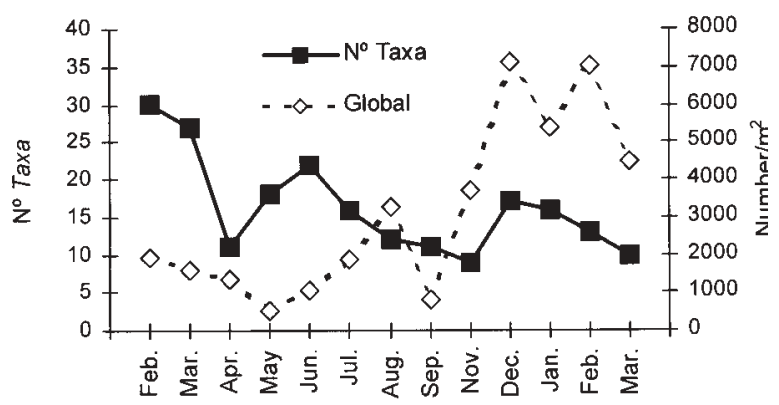

Figure 4. Number of taxa and global density of individuals (ind $\mathrm{m}^{-2}$ ) found in Lagoa da Sancha during February 1988 - March 1989. Número de taxones y densidad global de individuos (ind $\mathrm{m}^{-2}$ ) capturados en la laguna de Sancha desde Febrero de 1988 a Marzo de 1989.

dependence with rainfall regime. The suggestion is this lagoon is a former brackish lagoonal environment which has evolved towards a more limnetic condition, as the separating sand barrier between sea and lagoon widened. However, the lagoon remains a brackish oligohaline water body. This is clearly indicated by the presence of a large amount of taxa with brackish preferences (Table 2), both with marine and continental affinities (cf: Verhoeven \& Viersen, 1978, Barnes, 1980, Viersen \& Verhoeven, 1983, Cancela da Fonseca, 1989, Cancela da Fonseca, et al., 1989b, Quintino \& Rodrigues, 1989).

Phytoplankton in brackish environments is usually limited by nitrogen, contrasting with the commonly found P-limitation in freshwater systems (Nixon, 1982, Vaulot \& Frisoni, 1986). Concentrations of phosphate and nitrogen (i.e. ammonia, nitrite and nitrate) found in Lagoa da Sancha from September 1988 suggest P-limitation of phytoplankton (Table 1).

The Macrobenthic community is strongly dominated by Chironomids and Anomopoda species. Although there is large variation throughout the year, there was a generally large diversity of insects, with 54 taxa recorded, although their presence in the water was mostly limited to larval stages. Also, abundance of the different insect species was related to their different life cycle. 


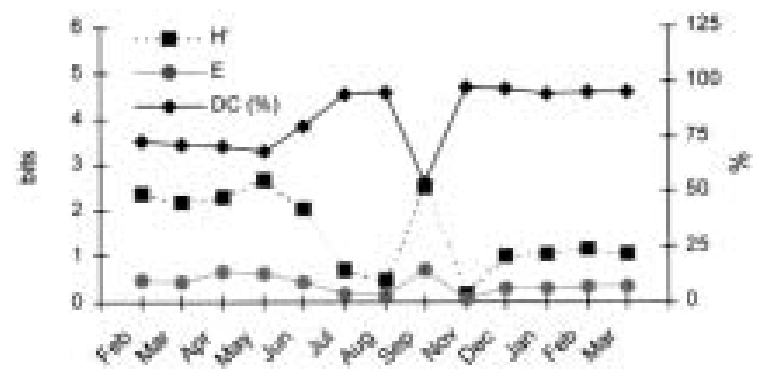

Figure 5. Species diversity (H'), equitability (E) and McNaugthon dominance (Dc) of the benthic community of Lagoa da Sancha estimated during the period February 1988 - March 1989. Diversidad de especies $\left(H^{\prime}\right)$. Equitabilidad (E) y indice de dominancia de McNaugthon (Dc) de la comunidad bentónica de la Laguna de Sancha durente el período de Febreo de 1988 a Marzo de 1989.

Monthly mean values of salinity and temperature emphasise that the change from oligohaline to mesohaline status occurs only during summer, due to evaporation (Table 1). During this study, sea water never entered the lagoon by the inlet and a single overwash period (December 1988 January 1989) was detected. Thu, little immigration from near by marine environments (Table 2 and Fig. 3) explains the scarcity of brackish species with marine affinities (Hediste diversicolor, Paranais litoralis, Cyprideis littoralis, Sphaeroma hookeri, Gammarus chevreuxi).

The lagoon was irregularly colonised by a wide diversity of taxa although many were only occasionally recorded. Only a restricted number of species appeared to tolerate the wide seasonal variation in environmental conditions (Table 2). As pointed out by Bamber et al. (1992), lagoons dominated by "lagoonal specialists" may be considered relevant for conservation as "ecological islands" or permanent habitats with periodical changes in environmental conditions (Cancela da Fonseca, 1979).

Changes in community parameters $\mathrm{H}^{\prime}, \mathrm{E}$ and Dc (Table5), suggest the heavy rainfall of January 1988 might have influenced the macroinvertebrate community by creating stable environmental conditions sustaining a steady diversity until May. The peak of diversity and simultaneous decline in dominance in September is probably related to the loss of chironomids, which disappeared from the water with their reaching adult phase.

Strong rainfalls were recorded in October and November followed by a dry winter leading to a community developed in winter wich differs from that of the previous winter. An increase in the number of taxa occurred in December, after a winter spate. The lentic communities were strongly influenced by temperature and salinity which is in turn dependent on annual climatic conditions. The benthic macroinvertebrate community of Lagoa da Sancha can be considered as a "physically controlled community" (Sanders, 1969).

In wet years the distance between sea and lagoon waters may be reduced, thus facilitating immigration of marine taxa coming with seawater washing over the sand barrier, a marine-lagoonal pool of species (Cancela da Fonseca, 1989; Cruz, 1989). Immigration, though, is sporadic and does not increase low winter salinity. In estuarine/lagoonal environments of the Portuguese Southwest coast, salinity seems to follow a annual cycle of decreases in Autumn-Winter, and increases in Spring-Summer due higher to runoff and evaporation (Andrade, 1986; Magalhães et al., 1987; Cancela da Fonseca, 1989; Cancela da Fonseca et al., 1989b).

The annual cycle of the benthos of Lagoa da Sancha has similarities to that of a neighbour lagoon, Lagoa de $\mathrm{St}^{\circ}$ André (Cancela da Fonseca, 1989). In both these lagoons, changes in the benthos community throughout the year in terms of species richness and diversity are a function of both the rates of immigration and of extinction (MacArthur \& Wilson, 1967). In effect, lagoons act as "ecological islands".

\section{ACKNOWLEDGEMENTS}

Thanks are due to Martinho Rangel, Fernando Simões and Assunção Rebelo for assistance in field sampling, and to Miguel Wallenstein, Gabriela Ramos and Maria Monteiro for sorting out organisms from samples. Thanks too to Martinho Rangel and Assunção Rebelo for help 
with laboratory work. This study was supported by the S.N.P.R.C.N. and the E.E.C., under the project "Estudos Base de Caracterização Física, Química e Biológica dos Biótopos Lagunares Costeiros das Lagoas de Santo André, Melides e Sancha". We are also grateful to Jeff Wallace for the English revision of the manuscript.

\section{REFERENCES}

ANDRADE, F. 1986. O estuário do Rio Mira: Caracterização geral e análise quantitativa da estrutura dos macropovoamentos bentónicos. Tese de Doutoramento, Univ. Lisboa, 393 pp.

BAMBER, R. N., S. D. BATTEN, M. SHEADER \& N. D. BRIDGWATER. 1992. On the ecology of brackish water lagoons in Great Britain. Aquatic Conservation: Marine and Freshwater Ecosystems, 2: 65-94.

BARNES, R.S.K., 1980. Coastal Lagoons. Cambridge University Press, Cambridge, 106 pp.

BERNARDO, J.M., A. M. COSTA \& L. CANCELA DA FONSECA, 1988. Nutrient dynamics and dystrophy in a brackish coastal lagoon (St. André, SW Portugal). Rapp. Comm. int. Mer Médit., 31(2): 61.

CANCELA DA FONSECA, J.P. 1979. Species colonisation models of temporary ecosystem habitats. In: Systems Analysis of Ecosystems. Innis, G. S. \& R.V. O'Neill (eds.): 125-195. Statistical Ecology Series, Vol.9. International Co-operative Publishing House. Burtonsville.

CANCELA DA FONSECA, L. 1989. Estudo da influência da "abertura ao mar" sobre um sistema lagunar costeiro: A Lagoa de Santo André. Tese de Doutoramento Univ. Lisboa, 355 pp.

CANCELA DA FONSECA, L. 1995. Caracterização das comunidades bentónicas da Lagoa de Santo André. Actas do $4^{\circ}$ Congresso sobre o Alentejo: 36-51.

CANCELA DA FONSECA, L., A. M. COSTA, J. M. BERNARDO \& R. FONSECA. 1987. Lagoa de Santo André (SW Portugal): Phytopigments as sedimentary tracers. Limnetica, 3(2): 299-306.

CANCELA DA FONSECA, L., A. M. COSTA \& J. M. BERNARDO. 1989a. Seasonal variation of benthic and fish communities in a shallow land-locked coastal lagoon (St. André, SW Portugal). Scient. Mar., 53(2-3): 663-669.

CANCELA DA FONSECA, L., A. M. COSTA \& M. CRISTO. 1989b. Caracterização do Macrobentos das Lagoas de Melides, Santo André e Sancha. Relatório. S.N.P.R.C.N. - Lisboa (mimeo), 179 pp.

CANCELA DA FONSECA, L., A. M. COSTA \& J. M. BERNARDO. 1990. Changes in a benthic community promoted by an artificial sea-connection in a brackish coastal lagoon (St. André, SW Portugal). Rapp. Comm. int. Mer Médit., 32(1): 178.

CANCELA DA FONSECA, L., A. M. COSTA \& J. M. BERNARDO. in litt.. Sistemas Lagunares do Litoral Alentejano. Actas das $1^{a s}$ Jornadas sobre o Património do Litoral Alentejano, APAC.

COLOMBO, G. 1977. Lagoons. In: The Coastline. Barnes, R. S. K. (ed.): 63-82. John Wiley \& Sons, Chichester.

COSTA, A.M., J. M. BERNARDO \& L. CANCELA DA FONSECA. 1985. Breve caracterização da evolução recente da Lagoa de Santo André (19781985). $1^{\circ}$ Congresso sobre o Alentejo, 3: 1429-1439.

CRISTO, M. \& L. CANCELA DA FONSECA, 1994. Growth of the common prawn Palaemon serratus (Pennant) and the common shrimp Crangon crangon (L.) in the St. André Lagoon (SW Portugal). Gaia, 8: 33-37.

CRUZ, T. 1989. Estrutura e dinâmica de uma comunidade de macrofauna bentónica na lagoa de Santo André - Quais os efeitos ecológicos da entrada natural de água oceânica sobre o cordão dunar? Tese de Licenciatura, Univ. Lisboa, 173 pp.

DUARTE, P., F. MAGALHÃES, J. E. FRANCO, \& L. CANCELA DA FONSECA. 1990. Trophic group patterns of macrobenthos: a way to understand macrobenthic communities? 9th Report on the Benthos Ecology Working Group - ICES: 49-53.

GRASSHOFF, K. (ed.) 1976. Methods of Seawater Analysis. Verlag Chemie, Weinheim: 317 pp.

KREBS, C. J. 1994. Ecology: The Experimental Analysis of Distribution and Abundance. (4 ${ }^{\text {th }}$ edition). Harper Collins College Publishers. 801 pp.

LORENZEN, C. J. 1967. Determination of chlorophyll and phaeopigments: spectrophotometric equations. Limnol. Oceanogr., 12: 343-346.

MACARTHUR, R. H. \& E. O. WILSON. 1967. The Theory of Island Biogeography. Princeton University Press, Princeton, N. J.

MAGALHÃES, F., L. CANCELA DA FONSECA, J. M. BERNARDO, A. M. COSTA, I. MOITA, I., J. E. FRANCO \& P. DUARTE. 1987. Physical characterisation of Odeceixe, Aljezur and Carrapateira lagoonal systems (SW Portugal). Limnetica, 3(2): 211-218.

NIXON, S. W. 1982. Nutrient dynamics, primary pro- 
duction and fishery yields of lagoons. Oceanologica Acta, N. Sp.: 357-371.

POSTMA, H. 1981. Processes in the sediments and in the water-sediment interface. UNESCO Tech. Pap. Mar. Sci., 33: 111-117.

QUINTINO, V. \& A. M. RODRIGUES. 1989. Environment gradients and distribution of macrozoobenthos in three Portuguese coastal systems: Óbidos, Albufeira and Alvor. In: Reproduction, genetics and distributions of marine organisms. Ryland, J. S. \& P. A. Tyler (eds.): 441-450. Olsen \& Olsen Pub., Fredensborg, Dk.

SANDERS, H. L. 1969. Benthic marine diversity and the Stability-Time Hypothesis. Brookhaven Symp. Biol., 22: 71-81.
STRICKLAND, J.D. \& T. R. PARSONS. 1972. A practical handbook for seawater analysis (2nd ed.). Bull. Fish. Res. Bd. Can., 167: 1-310.

VAULOT, D. \& G. F. FRISONI. 1986. Phytoplanktonic productivity and nutrients in five Mediterranean lagoons. Oceanologica Acta, 9(1): 57-63.

VERHOEVEN, J.T.A. \& W. VAN VIERSEN. 1978. Structure of macrophyte-dominated communities in two brackish lagoons on the island of Corsica, France. Aquatic Botany, 5: 77-86.

VIERSEN, W. VAN \& J. T. A. VERHOEVEN. 1983. Plant and animal communities in brackish supralittoral pools ('dobben') in the northern part of the Netherlands. Hydrobiologia, 98: 203-221. 